\title{
Internal and External Obstacles for Students in the Vocational Education Master Program in Thesis Preparation
}

\author{
Yeri Sutopo $^{1}$, Ely Rudyatmi ${ }^{2}$, Okta Purnawirawan ${ }^{1}$ \\ \{yerisutopo@mail.unnes.ac.id ${ }^{1}$, elyrudyatmi@mail.unnes.ac.id $\left.{ }^{2}\right\}$ \\ Vocational Education Master Program, Graduate School, Unnes ${ }^{1}$, Biology Study Program FMIPA \\ Unnes $^{2}$
}

\begin{abstract}
The objectives of this study was to analyze the inhibiting internal and external factors of students in Vocational Education Master Program in completing the thesis. This study employed descriptive survey method. The population in this study was the $4^{\text {th }}$ semester of Vocational Education Master Program students. Graduate students vocational education encounter obstacles in preparing a thesis on the medium category is 9.75\%; while $90.25 \%$ in the low category. The students of Vocational Education Master Program who experience internal obstacles in preparing a thesis in the medium category are $9.75 \%$; while $90.25 \%$ in the low category. Vocational Education students in the Master Program who experience external obstacles in preparing the thesis in the medium category are $21.95 \%$; while $78.05 \%$ in the low category. Conclusion the study were: (1) Internally students do not experience problems in preparing thesis; and (2) Externally the problem felt by students is in terms of cost.
\end{abstract}

Keywords: Vocational Education Master program; internal and external obstacles; thesis writing.

\section{Introduction}

The final project is students' scientific writing at a certain level arranged based on theoretical concepts and/or research results as requirements for their graduation and the acquisition of certain academic titles. The final project for students in doctorate program is a dissertation. The final project for students in master program is a thesis. The final project for students in the under graduate level is a thesis or final project or study project. The final project for students in diploma level is the final assignment of study [1].

The total credit hours at the Master program is at least 36 credits and a maximum of 50 credits which are scheduled for 2 academic years and can be taken in less than 2 academic years and for 4 academic years, including thesis preparation [2]. The cohort from 2013 academic year in Vocational Education Master Program until April 2018 have not graduated. It is indicated that they have not been able to prepare their thesis. This problem is caused by a variety of factors, including illness, lack of study costs, differences in perceptions of the substance of the thesis with their thesis supervisors, and not focusing on the process of completion.

Thesis is a scientific work arranged according to scientific rules by students under the guidance and supervision of the supervisor. According to the APA manual [3], scientific 
works can take the form of empirical studies, literature studies, case studies, theoretical studies, or methodological studies. In general, the thesis takes the form of empirical studies and case studies. Empirical study is a form of study that uses data obtained from actual observations or experiments. Empirical evidence obtained from observations was analyzed both quantitatively and qualitatively. Case studies are in-depth analysis of certain objects, such as individuals, groups, communities, or organizations. Case studies should be able to illustrate the problems and show how to solve the problem, and/or provide recommendations related to the research needed.

The thesis submission procedure is described as follows: (1) the student submits a thesis research proposal by filling out the Thesis Supervisor Application form and a statement of authenticity submitted to the Head of the Program accompanied by the Administrative Completion Statement; (2) The Head of the Program appoints a Thesis Supervisor based on the Decree of the Graduate School Director; (3) thesis research proposals that have been approved by the Supervisor and Head of the Program can then be continued in with a research proposal examination in accordance with the schedule approved by the supervisor; (4) approved research proposal is followed by research and thesis writing.

Sugiyono [4] explained the sources of academic writing problems in principle there are two, namely from internal and the second from external sources. JJ Siang [5] explains that the obstacles in completing a thesisare as follows (1) internal factors including lack of motivation in students and low academic ability; (2) external factors: the difficulty of finding ideas/problems used as thesis titles, difficulties in finding literature, and problems with supervisors during consultations. Obstacles faced by students in thesis guidance include the difficulty of meeting the supervisor because of the busy teaching schedule on campus, the length of the queue of other students who want to consult to the same supervisor, or the supervisor who is busy with the project because the project is nearing the appointed time. The above quote has the meaning that, barriers to internal factors are motivation in students and low academic ability [6].

The obstacles faced by the supervisor in conducting thesis supervision are because students do not have the commitment or discipline to quickly finish their thesis. For example, students rarely consult. However, when the thesis collection deadline is close, students are in a rush to consult so that the results are not optimal and by students, in such situations the supervisoris considered as not being helpful [7].(Hariyati, RM, 2012: 122).

\section{Methods}

This study employed the descriptive survey approach, namely research that takes samples from a population and uses a questionnaire as a basic data collection tool. This approach only involves one dependent variable [8]. The steps in this study were as follows: (1) formulating research problems and determining survey objectives; (2) determining concepts and hypotheses and exploring the literature, sometimes hypotheses are not needed; (3) sampling; (4) creating the questionnaire; (5) conducting field work, including selecting and training interviewers; (6) processing the data; and (7) analyzing and reporting the findings.

The population in this study was the $4^{\text {th }}$ semester students of Vocational Education master program. The sample in this study consisted of 41 students who were randomly selected. The data source of this research was $4^{\text {th }}$ semester students of Vocational Education Master Program and lecturers involved in thesis supervision. Therefore, a sample of supervisors were chosen 
based on the students, who were estimated to be 15 people. Another data source was the Coordinator of the Vocational Education Master Program.

The research data were collected by using a questionnaire aimed at students as a research sample. The instrument in this study was a questionnaire about the obstacles to completion of the thesis. The questionnaire about the obstacles of the students of the Vocational Education Master Program in completing the thesis was grouped into 2 sub-variables: academic and nonacademic obstacles. Questionnaires for lecturers related to the obstacles of students of Vocational Education Master Program in completing the thesis were grouped separately, to determine the extent of their involvement and effort in student thesis supervision.

The validity of this research instrument consisted of content and constructs validity. Content validity referred to the concept of obstacles in preparing a thesis. Construct validity tested the instrument whether the items had a significant loading factor and whether the items were fixed on the construct or not. The initial number of items was 49 while the amount is fallen items is 11 . Therefore, the number of valid items was 38. Based on the perspective of SEM, the construct reliability can be calculated through the following equation [9].

$$
C R=\frac{\left(\sum_{i=1}^{i} \ell_{i}\right)^{2}}{\left(\sum_{i=1}^{i} \ell_{i}\right)+\left(\sum_{i=1}^{i} \varepsilon\right)}
$$

Where:

$\mathrm{CR}=$ construct reliability

$\ell_{\mathrm{i}}=$ standardized indicator of loading factor $\mathrm{i}$

$\varepsilon=$ standard errormeasurement

The total valid items were 38 which consisted of 28 internal factors and 10 external factors. Internal factor reliability was 0.949 while the external factor was 0.885 ; while the composite reliability is 0.975 .

The criteria for processing the obstacle variables for the students in the Vocational Education Master Program in completing the thesis used the following criteria from Djemari Mardapi [10]. $\mathrm{SB}_{\mathrm{x}}$ is Standard deviation.

Table 1. Descriptive analysis of variables for students'obstacles in Vocational Education Master program in completing a thesis.

\begin{tabular}{lll}
\hline No. & Score range & Obstacles criteria \\
\hline 1. & $\bar{x}+1,0 S B_{x} \geq x \leq \bar{x}+3,0 S B_{x}$ & Low \\
2. & $\bar{x}-1,0 S B_{x} \geq x \leq \bar{x}+1,0 S B_{x}$ & Average \\
3. & $\bar{x}-3,0 S B_{x} \geq x \leq \bar{x}-1,0 S B_{x}$ & High \\
\hline
\end{tabular}

\section{Results and Discussion}

\subsection{Data Description of Obstacles in Completing Thesis Based on Internal Obstacles}

Table 2 shows that $9.75 \%$ of students experienced internal obstacles in the medium category in preparing a thesis; while $90.25 \%$ of students experienced internal barriers in the low category. Students who experienced internal obstacles in the high category are $0 \%$ or can 
be considered as nonexistent. Table 2 also shows that most students only experience internal obstacles in the low category in preparing a thesis.

Table 2. Description of students' internal obstacles in finishing their thesis.

\begin{tabular}{lllll}
\hline Range & Category & $\mathrm{f}_{\text {absolute }}$ & $\mathrm{f}_{\text {relative }}(\%)$ & $\mathrm{f}_{\text {cumulative }}(\%)$ \\
\hline $28-56$ & High & 0 & 0 & 0 \\
$56-84$ & Average & 4 & 9.75 & 9.75 \\
$84-112$ & Low & 37 & 90.25 & 9.75 \\
Total & & 41 & 100 & \\
\hline
\end{tabular}

Source: results of research data analysis, 2018

Where:

$\mathrm{f}$ : Frequency

Table 3 shows that the ability of students in writing hypotheses in the literature study chapter, the framework and hypothesis formulation in the thesis are still weak. The fact that can be stated that the description of the student research hypothesis is still non - directional. One of the characteristics of the research hypothesis is directional. One of the characteristics of directional hypotheses is "the higher the motivation of student learning participation, the higher the competency of students in counting". Most of the hypotheses in students' thesis was "there is a difference in the ability to draw clothes patterns between students who participated in the Jig Saw type of teaching and learning activities with students who participated expository teaching and learning". The hypothesis that the description is non - directional seems to ignore the description in the framework that has been built before.

Table 3. Description of internal obstacles experienced by students in completing a thesis.

\begin{tabular}{|c|c|c|c|}
\hline $\begin{array}{l}\text { No. of } \\
\text { Item }\end{array}$ & Description & $\begin{array}{l}\text { Average } \\
\text { score }\end{array}$ & Information \\
\hline 7 & $\begin{array}{l}\text { I have the ability to write } \\
\text { hypothesis in the literature review } \\
\text { chapter, the framework and } \\
\text { hypothesis formulation in the } \\
\text { thesis }\end{array}$ & 2.75 & $\begin{array}{l}34.14 \% \text { of } \\
\text { students have } \\
\text { low abilities }\end{array}$ \\
\hline 9 & $\begin{array}{l}\text { I have the ability to determine the } \\
\text { research analysis unit in the research } \\
\text { method chapter in the thesis }\end{array}$ & 2.83 & $\begin{array}{l}24.39 \% \text { of students } \\
\text { have low abilities }\end{array}$ \\
\hline 15 & $\begin{array}{l}\text { I have the ability to test the validity of } \\
\text { qualitative data in the thesis }\end{array}$ & 2.90 & $\begin{array}{l}19.51 \% \text { of students } \\
\text { have low ability }\end{array}$ \\
\hline 16 & $\begin{array}{l}\text { I have the ability to analyze } \\
\text { qualitative data in the thesis }\end{array}$ & 2.85 & $\begin{array}{l}21.95 \% \text { of students } \\
\text { have low abilities }\end{array}$ \\
\hline 31 & $\begin{array}{l}\text { I have the skills to operate software } \\
\text { such as SPSS or Lisrel in order to } \\
\text { complete the thesis }\end{array}$ & 2.85 & $\begin{array}{l}29.26 \% \text { of students } \\
\text { have low abilities }\end{array}$ \\
\hline
\end{tabular}

\subsection{Description of Data on Obstacles in Finishing Thesis Based on Their External Factors}

Table 4 shows that $21.95 \%$ of students experience external obstacles in the average category in preparing a thesis; while $78.05 \%$ of students experienced external obstacles in the low category. Students who experienced external obstacles in the high category were $0 \%$ or can be considered as non existent. Table 4 also shows that most students only experience external obstacles in the low category in preparing a thesis. 
Table 4. Description of student external obstacles in finishing the thesis.

\begin{tabular}{lllll}
\hline Range & Category & $\mathrm{f}_{\text {absolute }}$ & $\mathrm{f}_{\text {relative }}(\%)$ & $\mathrm{f}_{\text {cumulative }}(\%)$ \\
\hline $10-20$ & High & 0 & 0 & 0 \\
$20-30$ & Average & 9 & 21.95 & 21.95 \\
$30-40$ & Low & 32 & 78.05 & 100 \\
Total & & 41 & 100 & \\
\hline
\end{tabular}

Source: results of research data analysis, 2018

More in-depth analysis was carried out by paying attention to each internal obstacle of Vocational Education master program students in preparing a thesis, especially those with low scores (score <3). There were 5 items $(7,9,15,16$, and 31) whose total score is less than 3 . Descriptions of the items are presented in Table 5.

Table 5. Description of external obstacles experienced by students in completing a thesis.

\begin{tabular}{llll}
\hline $\begin{array}{l}\text { No. of } \\
\text { Item }\end{array}$ & Description & $\begin{array}{l}\text { Average } \\
\text { score }\end{array}$ & Information \\
\hline 44 & $\begin{array}{l}\text { I do not have problems in terms of } \\
\text { costs for completing a thesis }\end{array}$ & $\begin{array}{l}31.70 \% \text { of students } \\
\text { have problems in } \\
\text { terms of costs for } \\
\text { completing a thesis }\end{array}$ \\
\hline
\end{tabular}

Source: results of research data analysis, 2018

Table 5 shows that they relatively do not have external problems; from the family aspect, most of the students do not have problems; in terms of the supervisor aspect, students also do not have problems in terms of reference books. One of the problems of the students is costs of thesis completion. $31.70 \%$ of students have problems in terms of costs for completing a thesis. This is normal, because the few students has already worked but their salary is very small, because their occupation is contract teachers. Some or half of the students are fresh graduates, meaning that up to now there are still unemployed who rely on funding from parents. All students who are studying at the Vocational Education Master students are in their own cost category. The Graduate School has not provided scholarships from Ministry of Research, Technology and Higher Education.

\subsection{Data Description of Obstacles in Finishing Thesis}

Table 6 shows that $9.75 \%$ of students experienced obstacles in the medium category in preparing a thesis; while $90.25 \%$ of students experienced obstacles in the low category. Students who experienced obstacles in the high category are $0 \%$ or none. Table 6 also shows that a small proportion of students only experience obstacles in the low category in preparing a thesis. The results of this study are supported by data the average graduation time for Vocational Education Master Program students is 2 years 8 months. The deadline of graduating for students in the Vocational Education Master Program students is 3 years. The graduation time is categorized as a long time because some students from outside the city do not have a place to live in Semarang. Students leave early in the morning from a house outside the city and go home at night. However, the graduation time for students is still within the time frame specified by Graduate School, Unnes. The Achievement Index of graduates of Vocational Education Master Program students is 3.71 which falls into the very satisfying category; even if the graduation time is 2 years then it falls into the cumlaude category. 
Table 6. Description of student obstacles to finishing a thesis.

\begin{tabular}{lllll}
\hline Range & Category & $\mathrm{f}_{\text {absolute }}$ & $\mathrm{f}_{\text {relative }}(\%)$ & $\mathrm{f}_{\text {cumulative }}(\%)$ \\
\hline $38-76$ & High & 0 & 0 & 0 \\
$76-114$ & Average & 4 & 9.75 & 9.75 \\
$114-152$ & Low & 37 & 90.25 & 100 \\
Total & & 41 & 100 & \\
\hline
\end{tabular}

Source: results of research data analysis, 2018

\section{Conclusion}

Internally students do not experience problems in preparing thesis, however, if examined in depth then the ability of students in preparing hypotheses in the literature review chapter, the mindset and formulation of hypotheses in the thesis is still weak. Description of student research hypotheses tends to be undirectional, even though one of the characteristics of the research hypothesis is directional. This is natural, because when attending research methodology courses and seminar lecturers who have not yet had time to convey that the characteristics of the hypothesis is directional; this phenomenon may also occur because the material to be taught is very broad.

Externally the problem felt by students is in terms of cost. The number of students who have problems in terms of the cost of completing a thesis is $31.70 \%$. This is natural, because the average of them is already working but their salaries are very small, because their work is an honorary teacher or contract. Some or half of the students are fresh graduates, meaning that until now they are still unemployed who rely on sources of funding from parents. All students who are studying at the Vocational Education Master Program students at the Graduate School are included in their own expense category. Postgraduate has not provided scholarships from the Ministry of Research, Technology and Higher Education of the Republic of Indonesia.

Acknowledgments. Thank you to the Unnes Rector, Prof. Dr. H. Fathur Rohman, M.Hum ; who have provided funding for this research, through the Semarang State University Budget Implementation List (DIPA) Number: SP DIPA-042.01.2.400899 / 2018, December 5, 2017. In addition, thank you also to the Director of the Graduate School, Unnes Prof. Dr. H. Achmad Slamet, M.Sc. who have approved the Institutional Research Work Contract Agreement Number: 29.21.5 / UN37 / PPK.5.1 / 2018, May 21, 2018. 


\section{References}

[1]Unnes: Panduan akademik Unnes. Unnes Pres, Semarang (2016)

[2] Unnes: Pedoman penulisan tesis dan disertasi. Unnes Pres, Semarang (2014)

[3]George Forbes Memorial Library: APA style referencing. 6th Edition. Canterbury, Lincoln University (2010)

[4]Sugiyono: Cara mudah menyusun skripsi, tesis dan disertasi. Alfabeta, Bandung (2016)

[5]JJ.Siang: Cara cepat menyusun skripsi. Media Presindo, Jakarta (2009)

[6]Riduwan: Belajar mudah peneliti. Alfabeta, Bandung (2009)

[7]Hariyati, R. M.: Survey kinerja dosen pembimbing skripsi dan kualitas skripsi mahasiswa akuntansi STIE Malangkucecwara. Vol. 4, pp.121-128. Jurnal Dinamika Akuntansi, Malang (2012)

[8] Morissan: Metode penelitian survei. Kencana, Jakarta (2012)

[9]Margono, G.: Aplikasi analisis faktor konfirmatori untuk menentukan reliabilitas multi dimensi. Vol. 13, pp.17-24. Statistika, Jakarta (2013)

[10]Mardapi, Dj.: Teknik penyusunan tes dan nontes. Mitra Cendikia. Yogyakarta (2008) 